\title{
Comparative evaluation of the mutagenicity and genotoxicity of smoke condensate derived from Korean cigarettes
}

\author{
Ha Ryong Kim ${ }^{1}$, Jeong Eun Lee ${ }^{1}$, Mi Ho Jeong ${ }^{1}$, Seong Jin Choi ${ }^{2,3}$, Kyuhong Lee ${ }^{2,3}$, \\ Kyu Hyuck Chung ${ }^{1}$ \\ ${ }^{1}$ School of Pharmacy, Sungkyunkwan University, Suwon; ${ }^{2}$ Inhalation Toxicology Research Center, Korea Institute of Toxicology, \\ Jeongeup; ${ }^{3}$ Human and Environment Toxicology, University of Science and Technology, Daejeon, Korea
}

\begin{abstract}
Objectives Cigarette smoking is associated with carcinogenesis owing to the mutagenic and genotoxic effects of cigarette smoke. The aim of this study was to evaluate the mutagenic and genotoxic effects of Korean cigarettes using in vitro assays.

Methods We selected 2 types of cigarettes (TL and TW) as benchmark Korean cigarettes for this study, because they represent the greatest level of nicotine and tar contents among Korean cigarettes. Mutagenic potency was expressed as the number of revertants per $\mu \mathrm{g}$ of cigarette smoke condensate (CSC) total particulate matter whereas genotoxic potency was expressed as a concentration-dependent induction factor. The CSC was prepared by the International Organization for Standardization 3308 smoking method. CHO-K1 cells were used in vitro micronucleus (MNvit) and comet assays. Two strains of Salmonella typhimurium (Salmonella enterica subsp. enterica; TA98 and TA1537) were employed in Ames tests.

Results All CSCs showed mutagenicity in the TA98 and TA1537 strains. In addition, DNA damage and micronuclei formation were observed in the comet and MNvit assays owing to CSC exposure. The CSC from the $3 R_{4} F$ Kentucky reference (3R4F) cigarette produced the most severe mutagenic and genotoxic potencies, followed by the CSC from the TL cigarette, whereas the CSC from the TW cigarette produced the least severe mutagenic and genotoxic potencies.

Conclusions The results of this study suggest that the mutagenic and genotoxic potencies of the TL and TW cigarettes were weaker than those of the $3 R_{4} \mathrm{~F}$ cigarette. Further study on standardized concepts of toxic equivalents for cigarettes needs to be conducted for more extensive use of in vitro tests.
\end{abstract}

Keywords Cigarette smoke condensate, Mutagenicity, Genotoxicity, Ames test, Micronucleus assay, Comet assay

\section{Introduction}

Cigarette smoking is a prevalent phenomenon that is linked to many health problems, including heart attack, stroke, chronic obstructive pulmonary disease, cancer, and cardiovascular disease. In South Korea (hereafter Korea), cancer is currently the primary cause of death, while the mortality rate of lung cancer

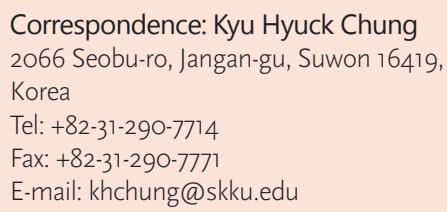

Tel: $+82-31-290-7714$

Fax: +82-31-290-7771

E-mail: khchung@skku.edu

Received: November 6, 2015 Accepted: December 11, 2015

Published online: December 13, 2015

This article is available from: http://e-eht.org/ 
Korea remains higher than the average rate of $27.5 \%$ in the adult populations of Organization for Economic Cooperation and Development (OECD) countries [3]. According to the Korea Youth Risk Behavior Web-based Survey conducted by the Korea Centers for Disease Control and Prevention, the smoking prevalence rate among male youths in Korea aged 13 to 18 years increased from $14.3 \%$ in 2005 to $16.3 \%$ in 2012 [4]. These statistics demonstrate that cigarette smoking remains a major public health problem in Korea and reveal the need for toxicological studies of cigarettes sold in the Korean market.

Since carcinogenesis may be induced by the mutagenic and genotoxic effects of cigarette smoke, the aim of this study was to evaluate the mutagenic and genotoxic effects of Korean cigarettes using in vitro assays. The tar and nicotine contents of cigarettes have been reported to be associated with mutagenic and genotoxic effects [5-8]. Packs of TL and TW cigarettes state that each cigarette contains $0.8 \mathrm{mg}$ nicotine and $8 \mathrm{mg}$ tar, which represent the highest level of nicotine and tar contents among around 60 kinds of Korean cigarettes produced in KT\&G in 2013. Therefore, we selected 2 types of cigarettes, TL and TW, as benchmark Korean cigarettes. The mutagenic and genotoxic potencies of the TL and TW cigarettes were compared to those of the 3R4F Kentucky reference (3R4F) cigarette. The cigarette smoke condensate (CSC) from each of the 3 tested types of cigarettes was evaluated for mutagenicity and genotoxicity using the Ames test, in vitro comet assay, and in vitro micronucleus (MNvit) assay. Mutagenic potency was expressed as the number of revertants per $\mu \mathrm{g}$ CSC total particulate matter (TPM), whereas genotoxic potency was expressed as a concentration-dependent induction factor (CDI), respectively.

\section{Materials and Methods}

\section{Cigarettes and Chemicals}

The 3R4F cigarette was kindly provided by the Korea Institute of Toxicology. The TL and TW were purchased from Korean commercial sources. Dimethyl sulfoxide (DMSO), phosphatebuffered saline (PBS), 2-aminoanthracene, benzo[a]pyrene and cytochalasin B were purchased from Sigma-Aldrich (St. Louis, MO, USA). Aroclor 1254-induced Sprague Dawley rat liver S9 was obtained from Moltox (Boone, NC, USA). The S9- cofactor, consisting of phosphate buffer, NADP, glucose 6-phosphate, $\mathrm{KCl}, \mathrm{MgCl}_{2}$ and $\mathrm{CaCl}_{2}$, was purchased from Wako (Tokyo, Japan).

\section{Preparation of Cigarette Smoke Condensates}

The cigarettes were stored at $22 \pm 1{ }^{\circ} \mathrm{C}$ with $60 \pm 2 \%$ relative humidity according to International Organization for Standardization (ISO) 3402 [9]. CSCs were generated by a 30-port smoking machine according to the ISO 3308 [10] smoking method ( $35 \mathrm{~mL}$ puff volume, 2 seceonds puff duration, $60 \mathrm{sec}-$ onds between puffs, and no vent blocking). All cigarettes were smoked to 3-mm beyond the end of the filter-tipping paper according to ISO 4387 [11]. Table 1 shows the contents of TPM, nicotine, and tar in the CSC from each type of cigarette. Each CSC was prepared by smoking 3 cigarettes of a particular type onto a Cambridge filter pad (44 mm; Whatman, Maidstone, UK), which was extracted with DMSO for 30 minutes with shaking, such that the final TPM concentration of the CSC was $20 \mathrm{mg} / \mathrm{mL}$. The CSC samples were filtered through $0.44 \mu \mathrm{m}$ sterile filters and frozen at $-80^{\circ} \mathrm{C}$.

\section{Cell Culture}

The CHO-K1 cell line was obtained from the Korea Cell Line Bank. CHO-K1 cells were grown in RPMI 1640 media with 5\% fetal bovine serum containing $2 \mathrm{mM} \mathrm{L}$-glutamine, $1 \%$ penicillin ( 100 units $/ \mathrm{mL}$ ), and $100 \mu \mathrm{g} / \mathrm{mL}$ streptomycin at $37^{\circ} \mathrm{C}$ in an atmosphere of $5 \% \mathrm{CO}_{2} / 95 \%$ air with saturated humidity.

\section{Ames Test}

Mutagenicity was tested based on OECD test guideline (TG) 471 [12]. Among the Salmonella typhimurium (Salmonella enterica subsp. enterica) strains including TA98, TA100, TA102, TA1535, and TA1537 tested in preliminary experiments, frameshift strains TA98 and TA1537 were found to be the most sensitive to CSC and employed in this work. In addition, the number of revertant colonies in most strains was not increased in the absence of S9 mix in preliminary experiments. Therefore, the Ames test was performed in the presence of the $\mathrm{S} 9 \mathrm{mix}$ using a plate incorporation method. Each CSC was combined with 100 $\mu \mathrm{L}$ of an overnight culture $\left(1-2 \times 10^{8} \mathrm{cfu} / \mathrm{mL}\right)$ of each strain and the $\mathrm{S} 9 \mathrm{mix}$, followed by incubation for 30 minutes at $37^{\circ} \mathrm{C}$.

Table 1. Characteristics of cigarettes (cig) used in this study

\begin{tabular}{llccc}
\hline Sample ID & \multicolumn{1}{c}{ Description } & TPM $(\mathrm{mg} / \mathrm{cig})$ & Nicotine $(\mathrm{mg} / \mathrm{cig})$ & Tar $(\mathrm{mg} / \mathrm{cig})$ \\
\hline 3R4F & Kentucky reference cigarette & 5.92 & 0.43 & 4.65 \\
TL & Korea benchmark design & 7.89 & 0.50 & 6.11 \\
TW & Korea benchmark design & 7.29 & 0.49 & 5.78 \\
\hline
\end{tabular}

TPM, total particulate matter. 
The control and CSC-treated strains were mixed with $2 \mathrm{~mL}$ of sterile top agar and poured onto minimal glucose agar plates. After the plates were incubated at $37^{\circ} \mathrm{C}$ for 48 hours, the number of revertant colonies on each plate was counted. The test was carried out with three plates per concentration. Test results were considered positive if the number of revertants was at least double the revertant number of negative control group for 2 consecutive concentrations and a concentration-related increase was observed in the number of revertants [13].

\section{Cell Viability Assay}

The CHO-K1 cells were seeded onto 96-well plates at a density of $5 \times 10^{3}$ cells/well. After the cells were cultured for 24 hours, they were treated with the CSC solutions for 24 hours, after which $10 \mu \mathrm{L}$ of WST-1 reagent (Roche Diagnostic, Montclair, NJ, USA) was added. The absorbance of each test sample was measured at $440 \mathrm{~nm}$ and $690 \mathrm{~nm}$ using a microplate reader. Cell viability was expressed as a percentage relative to that of the control cells.

\section{In Vitro Comet Assay}

The comet assay was performed as described by Singh et al. [14]. CHO-K1 cells were seeded on 6-well plates at a density of $4 \times 10^{5}$ cells/well. After 24 hours of incubation, the cultured cells were exposed to the CSCs for 3 hours in the presence of the S9 mix. The treated cells were resuspended in $0.7 \%$ low melting point agar. A $160-\mu \mathrm{L}$ aliquot of each cell suspension was spread onto a precoated glass slide and covered with a cover glass, after which the slide was incubated for 1 hour at $4{ }^{\circ} \mathrm{C}$. In the alkaline comet assay, cells were lysed in $\mathrm{pH} 10$ lysis solution at $4^{\circ} \mathrm{C}$ for 1 hour. The lysed cells were allowed to unwind for 30 minutes in electrophoresis buffer before electrophoresis for 30 minutes at $25 \mathrm{~V}$ on ice. The gels were neutralized with $0.4 \mathrm{M}$ Tris- $\mathrm{HCl}$ ( $\mathrm{pH} 7.5$ ) twice for 5 minutes and stained with ethidium bromide $(2 \mu \mathrm{g} / \mathrm{mL})$. DNA migration was assessed using automatic image analysis software. The Olive tail moment (OTM; tail distance $\times$ percentage of DNA in the tail) was used to quantify DNA damage based on random scoring of $100 \mathrm{nu}$ clei per slide. In order to compare DNA breakage induced by the 3 tested types of cigarettes, CDI was selected based on the report of Seitz et al. [15]. The CDI was calculated by integrating all concentrations and induction factors for each dose by the following equation:

$$
\mathrm{CDI}=\sum_{i=1}^{n} \frac{I F_{i}}{C_{i}}
$$

where $I F_{i}$ was the induction factor of the concentration, $C_{i}$ was the concentration $i(1-4)$, and $n$ was 4 ( 4 concentrations).

\section{In Vitro Micronucleus Assay}

MNvit assays were conducted in compliance with OECD TG 487 [16]. The treatment concentration of each CSC was determined by measuring the cytokinesis-block proliferation index $\mathrm{CHO}-\mathrm{K} 1$ cells were seeded onto 8-well chamber slides at a density of $1.5 \times 10^{4}$ cells/well for 24 hours. The cells were treated with the 4 doses of CSCs in the presence of the S9 mix for 3 hours, followed by a 21-hour recovery period under exposure to $0.75 \mu \mathrm{g} / \mathrm{mL}$ cytochalasin B. After washing the cells twice with PBS, $1 \%$ trisodium citrate was added for 5 minutes at $4^{\circ} \mathrm{C}$, after which the slides were placed in fixative solution at $4^{\circ} \mathrm{C}$. Ribonuclease $\mathrm{A}$ was added to each slide for 5 minutes at $30^{\circ} \mathrm{C}$, after which the slides were rinsed in $2 \times$ saline sodium citrate. After the slides were dried thoroughly, they were stained overnight with 5\% Giemsa solution with shaking. Micronuclei (MN) 1000 binucleated cells per duplicate culture (total 2000 binucleated cells) were scored by 2 scorers who were blind to the treatments. The CDI was calculated to allow comparison of the genotoxic potency of the 3 tested types of cigarettes using the MNvit assay.

\section{Statistical Analysis}

Sigma Plot (Jandel Scientific, San Rafael, CA, USA), Excel (Microsoft, Redmond, WA, USA), and SPSS version 21.0 (IBM Corp., Armonk, NY, USA) were used to analyze the data. The results of each assay are expressed as mean \pm standard deviation. Differences between groups were assessed by one-way ANOVA followed by Duncan's post-hoc test. Statistical significance was accepted at $p<0.05$ or 0.01 .

\section{Results}

\section{Mutagenic Potencies of Cigarette Smoke Condensates}

The mutagenicity of 3 CSCs was evaluated using the TA98 and TA1537 strains with the S9 mix. The revertant number of negative control group in the TA98 and TA1537 strains were $49.9 \pm 5.2$ and $16.7 \pm 1.9 \mathrm{rev} /$ plate, respectively. In both tested strains, CSC exposure dose-dependently increased the number of revertants in comparison with those of the corresponding negative control groups. According to the 2-fold rule, all CSCs showed positive results for mutagenicity in the TA98 and TA1537 strains (Table 2). The mutagenic potencies of the 3 tested CSCs are expressed as revertants per $\mu \mathrm{g}$ TPM as Mladjenovic et al. 's report (Table 3) [17]. The mutagenic potencies of CSCs from 3R4F, TL, and TW cigarettes were $1.99 \pm 1.00$, $1.15 \pm 0.20$, and $1.13 \pm 0.25 \mathrm{rev} / \mu \mathrm{g}$ TPM, respectively, in the TA98 strain. The mutagenic potency of the 3R4F CSC was approximately 1.8-fold higher than the mutagenic potency of the TL and TW CSCs. The TA1537 strain also showed a mutagenic 
Table 2. Mutagenicity of 3 CSCs in Salmonella typhimurium

\begin{tabular}{|c|c|c|c|c|c|c|}
\hline \multirow{2}{*}{$\begin{array}{l}\text { Dose } \\
\text { ( } \mu \mathrm{g} \text { TPM/plate) }\end{array}$} & \multicolumn{3}{|c|}{ TA98 } & \multicolumn{3}{|c|}{ TA1537 } \\
\hline & $3 \mathrm{R} 4 \mathrm{~F}$ & TL & TW & $3 R 4 F$ & TL & TW \\
\hline 0 & $49.9 \pm 5.2$ & & & $16.7 \pm 1.9$ & & \\
\hline 25 & $84.0 \pm 9.9^{\star}$ & $40.6 \pm 0.4$ & $41.8 \pm 4.3$ & $24.8 \pm 5.3$ & $13.8 \pm 1.5$ & $14.8 \pm 2.3$ \\
\hline 50 & $185.0 \pm 17.0^{\star *}$ & $61.0 \pm 10.5$ & $48.2 \pm 1.1$ & $34.5 \pm 1.3^{\star *}$ & $23.5 \pm 1.4^{\star *}$ & $16.8 \pm 2.0$ \\
\hline 100 & $231.3 \pm 18.0^{\star *}$ & $115.2 \pm 8.6^{\star \star}$ & $114.7 \pm 11.9^{* \star}$ & $39.8 \pm 1.1^{* *}$ & $29.5 \pm 2.6^{\star *}$ & $22.8 \pm 2.5^{\star}$ \\
\hline 200 & $272.7 \pm 21.2^{\star \star}$ & $224.3 \pm 16.4^{\star *}$ & $204.8 \pm 13.3^{* *}$ & $51.0 \pm 5.7^{\star \star}$ & $52.8 \pm 2.4^{\star *}$ & $34.0 \pm 0.7^{* *}$ \\
\hline 300 & $346.0 \pm 19.7^{\star \star}$ & $293.4 \pm 12.2^{\star *}$ & $321.7 \pm 4.0^{\star *}$ & $58.8 \pm 5.3^{\star \star}$ & $51.7 \pm 5.1^{\star \star}$ & $55.0 \pm 7.8^{* *}$ \\
\hline 400 & $335.0 \pm 22.6^{\star \star}$ & $368.4 \pm 17.3^{* *}$ & $340.6 \pm 0.4^{* *}$ & $60.5 \pm 7.1^{\star *}$ & $51.3 \pm 2.5^{\text {** }}$ & $56.2 \pm 1.6^{* *}$ \\
\hline 2-aminoanthracene & $277 \pm 30.1^{a \star \star}$ & & & $178.6 \pm 13.7^{b \star *}$ & & \\
\hline
\end{tabular}

Values are presented as mean \pm standard deviation. Values significantly different from control ( $0 \mu \mathrm{g} / \mathrm{plate})$. The inhibitory effect of CSCs on cell growth was observed in the tested strains at concentrations of $500 \mu \mathrm{g} /$ plate and higher.

CSC, cigarette smoke condensate; TPM, total particulate matter; 3R4F, 3R4F Kentucky reference.

aThe concentration of 2-aminoanthracene was $1 \mu \mathrm{g} /$ plate.

${ }^{\mathrm{b}}$ The concentration of 2-aminoanthracene was $10 \mu \mathrm{g} /$ plate.

${ }^{*} p<0.05,{ }^{* *} p<0.01$.

Table 3. Mutagenic and genotoxic potencies (rankings) of 3 CSCs

\begin{tabular}{|c|c|c|c|c|c|c|c|c|}
\hline \multirow{2}{*}{$\operatorname{cSC}$} & \multicolumn{4}{|c|}{ Ames test } & \multicolumn{2}{|c|}{ Comet assay } & \multicolumn{2}{|c|}{ MNvit assay } \\
\hline & 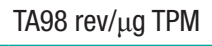 & Ranking & 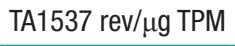 & Ranking & $\mathrm{CDI} / \mu \mathrm{g} \mathrm{TPM} / \mathrm{mL}$ & Ranking & $\mathrm{CDI} / \mu \mathrm{g} \mathrm{TPM} / \mathrm{mL}$ & Ranking \\
\hline $3 R 4 F$ & 1.99 & 1 & 0.39 & 1 & 1.41 & 1 & 1.11 & 1 \\
\hline TL & 1.15 & 2 & 0.32 & 2 & 1.32 & 2 & 1.02 & 2 \\
\hline TW & 1.13 & 3 & 0.29 & 3 & 0.69 & 3 & 0.93 & 3 \\
\hline
\end{tabular}

CSC, cigarette smoke condensate; MNvit assay, in vitro micronucleus assay; rev, revertants; TPM, total particulate matter; CDI, concentration-dependent induction factor; 3R4F, 3R4F Kentucky reference.

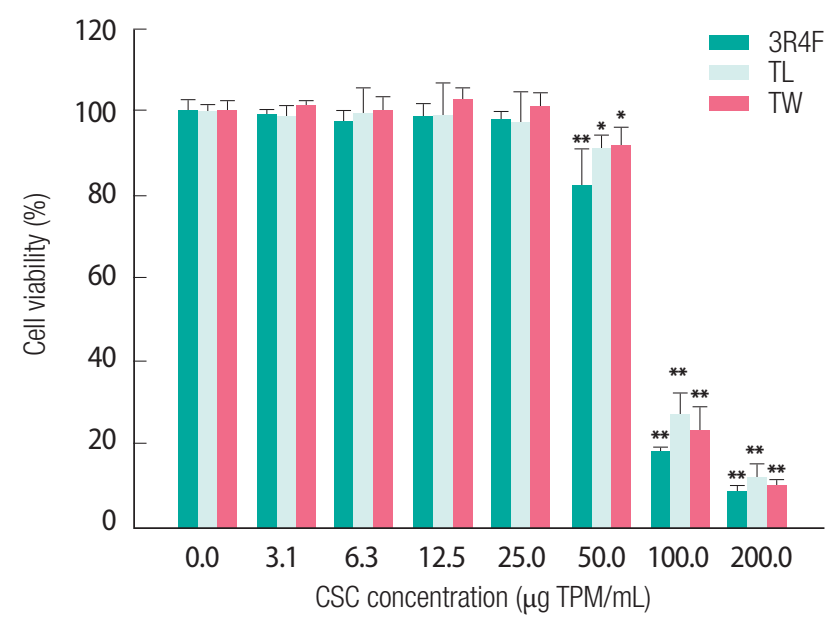

Figure 1. Viability of CHO-K1 cells exposed to 3 CSCs. The cells were incubated with 3R4F (green bar), TL (sky blue bar), and TW (red bar) CSCs. for 24 hours, after which the WST-1 assay was performed. Cell viability was expressed as a percentage of that of the control cells $(0.0 \mu \mathrm{g}$ TPM per $\mathrm{mL}$ ). Each value represents the mean \pm standard deviation of 5 separate experiments. CSCs, cigarette smoke condensates; 3R4F, 3R4F Kentucky reference; TPM, total particulate matter. ${ }^{*} p<0.05,{ }^{\star *} p<0.01$ for values significantly different from those of the control group.

response to the CSCs, but the CSCs were less potent than they were in the TA98 strain. The mutagenic potencies of the CSCs from 3R4F, TL, and TW cigarettes were $0.39 \pm 0.30,0.32 \pm 0.15$, and $0.29 \pm 0.17 \mathrm{rev} / \mu \mathrm{g}$ TPM, respectively, in the TA1537 strain.

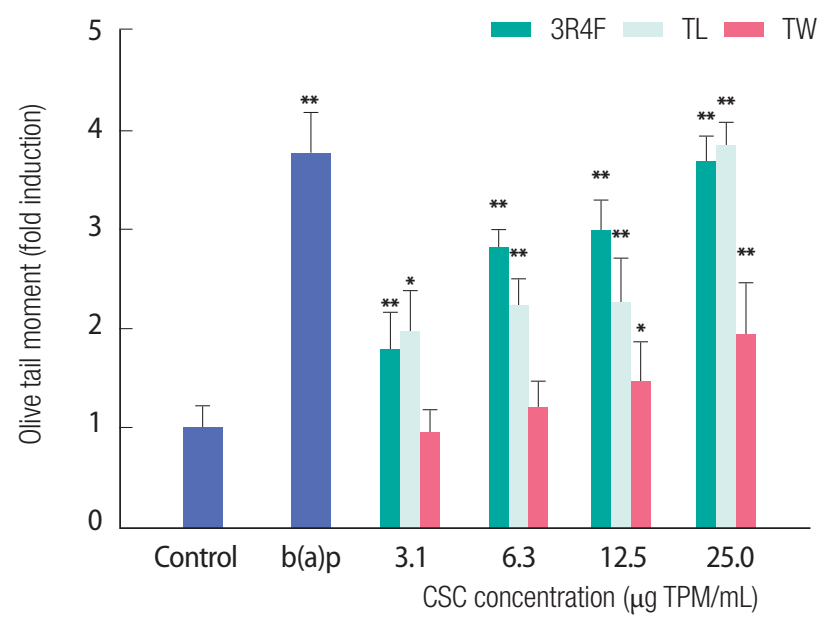

Figure 2. DNA breakage in CHO-K1 cells exposed to 3 CSCs. The cells were treated with 3R4F (green bar), TL (sky blue bar), and TW (red bar) CSCs. for 3 hours in the presence of the S9 mix. The positive control cells were exposed to $10 \mu \mathrm{M} \mathrm{b}(\mathrm{a}) \mathrm{p}$. DNA breakage was expressed as Olive tail moment (tail distance $\times \%$ DNA in the tail), which was expressed as a foldinduction relative to the control group ( $0.0 \mu \mathrm{g}$ TPM per $\mathrm{mL})$. Each value represents the mean \pm standard deviation of 5 separate experiments. CSCs, cigarette smoke condensates; 3R4F, 3R4F Kentucky reference; b(a) $p$, benzo[a]pyrene; TPM, total particulate matter. ${ }^{\star} p<0.05,{ }^{\star *} p<0.01$ for values significantly different from those of the control group.

In the TA98 and TA1537 strains, the 3R4F CSC had the greatest mutagenic potency, followed by the TL CSC, whereas the TW CSC had the lowest mutagenic potency. 


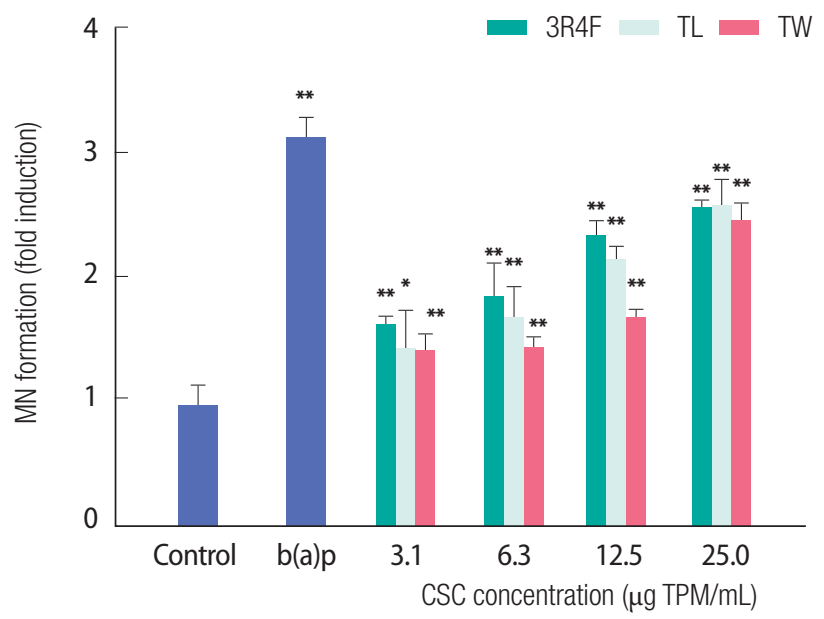

Figure 3. MN formation in $\mathrm{CHO}-\mathrm{K} 1$ cells exposed to $3 \mathrm{CSCs}$. The cells were treated with 3R4F (green bar), TL (sky blue bar), and TW (red bar) CSCs for 3 hours in the presence of S9 mix, followed by a 21-hour recovery period under exposure to $0.75 \mu \mathrm{g} / \mathrm{mL}$ cytochalasin B. The positive control cells were exposed to $5 \mu \mathrm{M} \mathrm{b}(\mathrm{a}) \mathrm{p}$. The CBPI of the cells treated with the 3R4F, TL, and TW CSCs at a concentration of $25.0 \mu \mathrm{g} / \mathrm{mL}$ were $1.75 \pm 0.03,1.76 \pm 0.05$, and $1.69 \pm 0.04$, respectively. Treatment with CSCs did not significantly reduce the CBPI of treated cells in comparison with that of the control cells $(1.77 \pm 0.04)$. The MN formation results are expressed as fold-induction relative to that of the control group $(0.0 \mu \mathrm{g}$ TPM per $\mathrm{mL}$ ). Each value represents the mean \pm standard deviation of 5 separate experiments. MN, micronuclei; CSCs, cigarette smoke condensates; 3R4F, 3R4F Kentucky reference; b(a)p, benzo(a)pyrene; CBPI, cytokinesis-block proliferation index; TPM, total particulate matter. ${ }^{*} p<0.05$ ${ }^{\star \star} p<0.01$ for values significantly different from those of the control group.

\section{Genotoxic Potencies of Cigarette Smoke Condensates}

Cytotoxicity tests were performed prior to DNA breakage evaluation to avoid false-positive results owing to interference with the genotoxicity assay by acute cell toxicity. Significant cytotoxicity was observed in cells treated with all CSCs at concentrations greater than $50 \mu \mathrm{g} \mathrm{TPM} / \mathrm{mL}$ (Figure 1). Therefore, the concentrations of CSCs used in the genotoxicity tests were 25 $\mu \mathrm{g}$ TPM $/ \mathrm{mL}$ or less. Figure 2 shows the dose-response curve of each CSC for DNA breakage. All CSCs dose-dependently increased DNA breakage. The CSCs from 3R4F and TL cigarettes significantly increased OTM at all tested concentrations, whereas the CSC from the TW cigarettes significantly increased OTM at concentrations of 12.5 and $25.0 \mu \mathrm{g}$ TPM $/ \mathrm{mL}$. The TL CSC produced more DNA damage ( $3.83 \pm 0.24$-fold) than the 3R4F (3.68 \pm 0.25 -fold) and TW (1.93 \pm 0.54 -fold) CSCs at a concentration of $25 \mu \mathrm{g} \mathrm{TPM} / \mathrm{mL}$. However, the CDI values produced by the 3R4F, TL, and TW CSCs were 1.41, 1.32, and $0.69 / \mu \mathrm{g} \mathrm{TPM} / \mathrm{mL}$, respectively (Table 3 ). In the MNvit assay, all tested CSC concentrations dose-dependently and significantly increased MN formation (Figure 3). Similar to the results of the comet assay, the TL CSC induced the highest frequency of $\mathrm{MN}$ formation (2.62 \pm 0.19 -fold), followed by the $3 \mathrm{R} 4 \mathrm{~F}$
(2.59 \pm 0.05 -fold $)$ and TW $(2.49 \pm 0.13$-fold $)$. However, the $\mathrm{CDI}$ values were $1.11,1.02$, and $0.93 / \mu \mathrm{g} \mathrm{TPM} / \mathrm{mL}$ in $3 \mathrm{R} 4 \mathrm{~F}$, $\mathrm{TL}$, and TW, respectively.

\section{Discussion}

Cigarette smoke is a deleterious and complex mixture of more than 7000 gaseous and particulate compounds, including at least 70 carcinogens [18]. The cytotoxicity, genotoxicity, and mutagenicity of commercial brands of cigarettes sold in Japan, the US, and Canada have been reported [19-21]. However, to the best of our knowledge, this study is the first report to evaluate the mutagenic and genotoxic effects of CSCs derived from Korean cigarettes and compare them with those of the 3R4F cigarette.

The mutagenic potencies of various commercial cigarettes have been evaluated in TA98 strain, because TA98 showed greater susceptibility to CSCs than other strains, including TA100 and TA1537 [22,23]. Mladjenovic et al. [17] reported that the mutagenic potencies of CSCs from 3 types of cigarettes chosen as benchmarks of Canadian commercial cigarettes were 0.6 to $0.7 \mathrm{rev} / \mu \mathrm{g}$ TPM, which corresponded to about half of the mutagenic potency of the 3R4F CSC. The mutagenic potencies of kretek cigarettes, a type of commercial cigarette originating from Indonesia, were approximately $1.1 \mathrm{rev} / \mu \mathrm{g}$ TPM in the TA98 strain with the S9 mix [24]. In addition, Japanese cigarettes with nicotine and tar contents similar to those in our samples showed mutagenic potencies of 0.73 to $1.19 \mathrm{rev} / \mu \mathrm{g}$ TPM in the TA98 strain with the S9 mix [19]. Therefore, based on calculated mutagenic potency, the mutagenic effects of TL (1.15

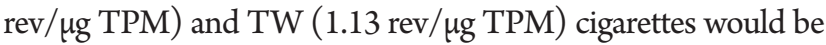
expected to be similar to those of previously tested foreign commercial cigarettes. In contrast, US commercial cigarettes had stronger mutagenic potency than Korean cigarettes. Virginia Slims are a brand of commercial cigarettes sold in the US that have similar nicotine and tar contents to the TL and TW cigarettes tested in our study. The mutagenic potencies of Virginia Slims cigarettes ranged from 3.37 to $4.23 \mathrm{rev} / \mu \mathrm{g}$ TPM in the TA98 strain with the S9 mix [20].

The genotoxic potencies of CSCs were expressed as CDIs, which were calculated from the induction factors at all concentrations. The CDI provides information that is adequate for straightforward, precise, and realistic assessment of genotoxic potential by integrating responses to compounds across wide concentration ranges [15]. However, the CDI may overestimate effects at low concentrations, because substances with minor genotoxic effects at low concentrations tend to result in higher CDIs than substances with very strong effects at high concentra- 
tions [25]. The CDI value of 3R4F CSC was the greater than that of TL and TW CSCs in both comet and MNvit assays. This result was consistent with the relative mutagenicity potencies of the 3 tested CSCs. After all, the CSC from the 3R4F cigarette produced the most severe mutagenic and genotoxic potencies, followed by the CSC from the TL cigarette, whereas the CSC from the TW cigarette produced the least severe mutagenic and genotoxic potencies (Table 3). However, our results do not indicate that domestic cigarettes typically have weaker mutagenicity and genotoxicity than foreign cigarettes, since the $3 \mathrm{R} 4 \mathrm{~F}$ cigarette is not represented cigarettes on sale in entire US cigarette market.

The tar and nicotine contents of cigarettes have been reported to be associated with smoking-related diseases such as lung cancer. The level of daily exposure to cigarette tar was a positive significant predictor of genotoxicity [5]. In addition, smokers of lower tar cigarettes had a risk of lung cancer $23 \%$ lower than that of smokers of higher tar cigarettes [6]. Although nicotine itself is not classified as a carcinogen, nicotine may contribute to the carcinogenic effects of cigarette owing to its genotoxic properties [7]. However, a few studies reported that the mutagenic activities of so-called low-tar brands are not always less than that of the other brands $[19,26]$. These findings are supported by epidemiologic studies that demonstrate no difference in lung cancer risk among smokers of cigarettes having tar levels of regular, light and ultralight [27]. Some studies also reported that nicotine and its major metabolites are not genotoxic [28] and that mutagenic effects induced by cigarettes are not related to nicotine content [29]. The role of tar in mutagenic and genotoxic effects induced by CSCs is harder to explain in this study, because CSCs derived from 3 types of cigarettes have similar content of tar in TPM. The 3R4F cigarette contained the highest nicotine of $72.64 \mathrm{mg} / \mathrm{g}$ TPM and showed higher mutagenicity and genotoxicity than TL or TW with 63.37 and $67.21 \mathrm{mg} / \mathrm{g}$ TPM. However, there is inconsistency between the content of nicotine in TPM and rankings of genotoxic potency, assuming that cigarettes properties other than a single nicotine value influence the mutagenicity and genotoxicity of the cigarettes.

In vitro testing has been accepted as a screening method to determine the potential toxicity of tobacco products. Nevertheless, in vitro toxicity data from studies of cigarettes rarely exerts influence on cigarette-related policies enacted by national authorities. There are several causes for the lack of influence of research data on policy decisions, but a critical cause of this issue is that it is difficult to compare the mutagenic and genotoxic properties of different types of cigarettes. In order to provide a method for comparative assessment of the mutagenic and genotoxic effects of different types of cigarettes, standardized concepts of toxic equivalents must be developed. The mutagenicity of CSCs is often expressed as the number of revertants per $\mu \mathrm{g}$ or $\mathrm{mg}$ TPM, allowing direct comparisons of the mutagenic potencies of CSCs. However, the genotoxicity of CSCs cannot usually be compared directly, because there is no standardized or commonly used method for quantifying the genotoxic effects of CSCs. In this study, we evaluated the mutagenic and genotoxic effects of Korean cigarettes and compared them to those of $3 \mathrm{R} 4 \mathrm{~F}$ cigarettes. The mutagenic and genotoxic potencies of the tested CSCs were calculated as the number of revertants per $\mu \mathrm{g}$ TPM in the Ames test and CDI values in comet and MNvit assays, respectively. The mutagenic and genotoxic potencies of the 3R4F CSC were greater than those of the TL CSC, which were greater than those of the TW CSC. Further study on standardized concepts of toxic equivalents for cigarettes needs to be conducted for more extensive use of in vitro tests.

\section{Conflict of Interest}

The authors have no conflicts of interest associated with material presented in this paper.

\section{ORCID}

Ha Ryong Kim http://orcid.org/0000-0003-3586-2279

Jeong Eun Lee http://orcid.org/0000-0001-8204-1786

Mi HoJeong http://orcid.org/0000-0003-4626-6317

Seong Jin Choi http://orcid.org/0000-0002-3918-7381

Kyuhong Lee http://orcid.org/0000-0003-4123-341X

Kyu Hyuck Chung http://orcid.org/0000-0003-4283-0742

\section{REFERENCES}

1. Jung KW, Won YJ, Kong HJ, Oh CM, Cho H, Lee DH, et al. Cancer statistics in Korea: incidence, mortality, survival, and prevalence in 2012. Cancer Res Treat 2015;47(2):127-141.

2. Ha BM, Yoon SJ, Lee HY, Ahn HS, Kim CY, Shin YS. Measuring the burden of premature death due to smoking in Korea from 1990 to 1999. Public Health 2003;117(5):358-365.

3. Ministry of Health and Welfare. Yearbook of health, welfare and family statistics 2009. Seoul: Ministry of Health and Welfare; 2012, p. 39 (Korean).

4. Choi SH. Smoking status of adults and adolescents in Korea. Public Health Wkly Rep KCDC 2013;6(35):702-706 (Korean).

5. Lu Y, Morimoto K. Exposure level to cigarette tar or nicotine is associated with leukocyte DNA damage in male Japanese smokers. Mutagenesis 2008;23(6):451-455.

6. Lee PN. Lung cancer and type of cigarette smoked. Inhal Toxicol 2001;13(11):951-976.

7. Grando SA. Connections of nicotine to cancer. Nat Rev Cancer 
2014;14(6):419-429.

8. Nersesyan A, Muradyan R, Kundi M, Knasmueller S. Impact of smoking on the frequencies of micronuclei and other nuclear $\mathrm{ab}-$ normalities in exfoliated oral cells: a comparative study with different cigarette types. Mutagenesis 2011;26(2):295-301.

9. International Organization of Standardization. Tobacco and tobacco products: atmosphere for conditioning and testing. ISO 3402. Geneva: International Organization of Standardization; 1999, p. 1-5.

10. International Organization of Standardization. Routine analytical cigarette-smoking machine: definitions and standard conditions. ISO 3308. Geneva: International Organization of Standardization; 2012, p. 1-25.

11. International Organization of Standardization. Cigarettes: determination of total and nicotine-free dry particulate matter using a routine analytical smoking machine. ISO 4387. Geneva: International Organization of Standardization; 2000, p. 1-17.

12. Organization for Economic Cooperation and Development. Bacterial reverse mutation test. OECD guideline for testing of chemicals 471. Paris: Organization for Economic Cooperation and Development; 1997, p. 1-11.

13. Cariello NF, Piegorsch WW. The Ames test: the two-fold rule revisited. Mutat Res 1996;369(1-2):23-31.

14. Singh NP, McCoy MT, Tice RR, Schneider EL. A simple technique for quantitation of low levels of DNA damage in individual cells. Exp Cell Res 1988;175(1):184-191.

15. Seitz N, Böttcher M, Keiter S, Kosmehl T, Manz W, Hollert H, et al. A novel statistical approach for the evaluation of comet assay data. Mutat Res 2008;652(1):38-45.

16. Organisation for Economic Cooperation and Development. Test No. 487: in vitro mammalian cell micronucleus test; 2014 [cited 2015 Dec 10]. Available from: http://www.oecd-ilibrary.org/environment/test-no-487-in-vitro-mammalian-cell-micronucleustest 9789264091016-en.

17. Mladjenovic N, Maertens RM, White PA, Soo EC. Mutagenicity of smoke condensates from Canadian cigarettes with different design features. Mutagenesis 2014;29(1):7-15.

18. US Department of Health and Human Services. The health consequences of smoking- 50 years of progress: a report of the Surgeon General, 2014 [cited 2015 Dec 10]. Available from: http://www. surgeongeneral.gov/library/reports/50-years-of-progress/.
19. Endo O, Matsumoto M, Inaba Y, Sugita K, Nakajima D, Goto S, et al. Nicotine, tar, and mutagenicity of mainstream smoke generated by machine smoking with International Organization for Standardization and Health Canada Intense regimens of major Japanese cigarette brands. J Health Sci 2009;55(3):421-427.

20. Roemer E, Stabbert R, Rustemeier K, Veltel DJ, Meisgen TJ, Reininghaus $\mathrm{W}$, et al. Chemical composition, cytotoxicity and mutagenicity of smoke from US commercial and reference cigarettes smoked under two sets of machine smoking conditions. Toxicology 2004;195(1):31-52.

21. Rickert WS, Trivedi AH, Momin RA, Wagstaff WG, Lauterbach $\mathrm{JH}$. Mutagenic, cytotoxic, and genotoxic properties of tobacco smoke produced by cigarillos available on the Canadian market. Regul Toxicol Pharmacol 2011;61(2):199-209.

22. Tewes FJ, Meisgen TJ, Veltel DJ, Roemer E, Patskan G. Toxicological evaluation of an electrically heated cigarette. Part 3: genotoxicity and cytotoxicity of mainstream smoke. J Appl Toxicol 2003;23(5): 341-348.

23. Aufderheide M, Gressmann H. A modified Ames assay reveals the mutagenicity of native cigarette mainstream smoke and its gas vapour phase. Exp Toxicol Pathol 2007;58(6):383-392.

24. Roemer E, Dempsey R, Hirter J, Deger Evans A, Weber S, Ode A, et al. Toxicological assessment of kretek cigarettes Part 6: the impact of ingredients added to kretek cigarettes on smoke chemistry and in vitro toxicity. Regul Toxicol Pharmacol 2014;70 Suppl 1:S66-S80.

25. Fassbender C, Braunbeck T, Keiter SH. Gene-TEQ--a standardized comparative assessment of effects in the comet assay using genotoxicity equivalents. J Environ Monit 2012;14(5):1325-1334.

26. Guo X, Verkler TL, Chen Y, Richter PA, Polzin GM, Moore MM, et al. Mutagenicity of 11 cigarette smoke condensates in two versions of the mouse lymphoma assay. Mutagenesis 2011;26(2):273281.

27. Harris JE, Thun MJ, Mondul AM, Calle EE. Cigarette tar yields in relation to mortality from lung cancer in the cancer prevention study II prospective cohort, 1982-8. BMJ 2004;328(7431):72.

28. Doolittle DJ, Winegar R, Lee CK, Caldwell WS, Hayes AW, de Bethizy JD. The genotoxic potential of nicotine and its major metabolites. Mutat Res 1995;344(3-4):95-102.

29. Mizusaki S, Okamoto H, Akiyama A, Fukuhara Y. Relation between chemical constituents of tobacco and mutagenic activity of cigarette smoke condensate. Mutat Res 1977;48(3-4):319-325. 